\title{
Neuroprotective effects of proanthocyanidins of grape seed extracts against oxidative stress and apoptosis induced by 6-hydroxydopamine in $\mathrm{PC} 12$ cells
}

\section{Efeito neuroprotetor de protocianidinas extraida da semente de uva frente ao extresse oxidativo e apoptose induzido pela 6-hidroxidopamina em células PC12}

\author{
Patrícia de Araújo Rodrigues ${ }^{1,2 *}$, Selene Maia de Morais ${ }^{3,4}$, Juliana Fernandes Pereira ${ }^{1,2}$, \\ Albert Layo Costa de Assis ${ }^{1,2}$, Amanda Aragão Alves ${ }^{2,5}$, Stephen Rathinaraj Benjamin ${ }^{1,2}$, \\ Ícaro Gusmão Pinto Vieira ${ }^{3}$, Marta Regina Santos do Carmo ${ }^{2,5}$, Geanne Matos de Andrade 1,2,5
}

${ }^{1}$ Post-Graduate Programme in Medical Sciences, Department of Medicine, Faculty of Medicine, Federal University of Ceará, Fortaleza, Brazil.

${ }^{2}$ Drug Research and Development Center (NPDM), Fortaleza, Brazil.

${ }^{3}$ Department of Chemistry, State University of Ceará, Fortaleza, Brazil.

${ }^{4}$ Northeast Network of Biotechnology, RENORBIO, Fortaleza, Brazil.

${ }^{5}$ Post-Graduate Programme in Pharmacology, Department of Physiology and Pharmacology, Federal University of Ceará, Fortaleza, Brazil.

*E-mail: patricia_lpn@yahoo.com.br.br

\begin{abstract}
Parkinson's disease (PD) is a neurological disorder characterized by dopaminergic neuronal destruction. Due to the obvious existence of polyunsaturated fatty acids (PUFA) mostly in grape seeds, Vitis Vinifera $\mathrm{L}$ was more commonly used in cardiovascular diseases. The objective of this study was to investigate the role of proanthocyanidins from grape seed extract exhibited neurocytoprotective effects against 6hydroxydopamine (6-OHDA)-induced cytotoxicity in PC12 cells, prevented the depletion of GSH content, and reduced nitrite and malondialdehyde levels. The cells were pretreated with proanthocyanidins (100 $\mu \mathrm{g} / \mathrm{ml}$ ) and subsequently exposed to 6-OHDA at $50 \%$ of lethal concentration. Our results demonstrated that PA response in PC12 cells significantly increased the cell viability, decreased cytotoxicity. The OHDAinduced apoptosis activity was determined by flow cytometry using annexin $\mathrm{v}$ and cleaved caspase- 3 and caspase-7 expression were analysed by western blot. In addition, we measured oxidative stress markers such as; MDA, GSH, and nitrite levels in PC12 cells. Proanthocyanidins prevented 6-OHDA-induced cytotoxicity, prevented the depletion of GSH content, and reduced nitrite and malondialdehyde levels. Moreover, proanthocyanidins attenuated the 6-OHDA-induced decrease of the cleaved caspase-3 and caspase-7 proteins. These results suggest that proanthocyanidins protect PC12 cells against 6-OHDAinduced neurotoxicity through antioxidant and apoptotic activity.
\end{abstract}

Keywords: proanthocyanidins; parkinson's disease; oxidative stress; apoptosis; PC12 cells.

\section{RESUMO}

A doença de Parkinson (DP) é um distúrbio neurológico caracterizado pela destruição neuronal dopaminérgica. Devido à óbvia existência de ácidos graxos poliinsaturados (PUFA) principalmente em sementes de uva, Vitis Vinifera L era mais comumente usado em doenças cardiovasculares. O objetivo deste estudo foi investigar o papel das proantocianidinas do extrato de semente de uva exibindo efeitos neurocitoprotetores contra a citotoxicidade induzida por 6-hidroxidopamina (6-OHDA) em células PC12, 
prevenindo a depleção do conteúdo de GSH e reduzindo os níveis de nitrito e malondialdeído. As células foram pré-tratadas com proantocianidinas $(100 \mu \mathrm{g} / \mathrm{ml})$ e subsequentemente expostas a 6-OHDA a $50 \%$ da concentração letal. Nossos resultados demonstraram que a resposta ao PA em células PC12 aumentou significativamente a viabilidade celular, diminuiu a citotoxicidade. A atividade de apoptose induzida por OHDA foi determinada por citometria de fluxo usando anexina $v$ e caspase-3 clivada e expressão de caspase-7 foram analisadas por western blot. Além disso, medimos marcadores de estresse oxidativo, como; Níveis de MDA, GSH e nitrito em células PC12. As proantocianidinas preveniram a citotoxicidade induzida por 6-OHDA, preveniram a depleção do conteúdo de GSH e reduziram os níveis de nitrito e malondialdeído. Além disso, as proantocianidinas atenuaram a redução induzida por 6-OHDA das proteínas caspase-3 e caspase-7 clivadas. Esses resultados sugerem que as proantocianidinas protegem as células PC12 contra a neurotoxicidade induzida pela 6-OHDA por meio da atividade antioxidante e apoptótica.

Palavras-chave: protocianidinas; doença de Parkinson; extresse oxidativo, apoptose, PC12

\section{INTRODUCTION}

Parkinson's disease (PD) is the second most prevalent neurodegenerative disorder behind Alzheimer's disease (AD) and is characterized by the loss of dopaminergic neurons in the substantia nigra pars compacta, reducing dopamine biosynthesis in the substantia nigra and striatum (FEARNLEY; LEES, 1991). The clinical characteristics of PD are common motor symptoms including slowness of movement, rigidity, balance dysfunction, and tremor (MORIGUCHI; YABUKI; FUKUNAGA, 2012). Furthermore, depression, anxiety, dementia, and autonomic dysfunction also being common (BAGLIO et al., 2011). Several factors are associated with neuronal degeneration in PD including oxidative stress, mitochondrial dysfunction, and alpha-synuclein aggregation (DAUER; PRZEDBORSKI, 2003). Oxidative stress is mediated by reactive oxygen species (ROS), including free radicals such as superoxide ions (O2-) and hydroxyl radicals $(. \mathrm{OH})$ as well as non-free radical species such as hydrogen peroxide (H2O2), which are generated as by-products of normal and aberrant metabolic processes that utilize molecular oxygen (SHUI GUAN et al., 2006). ROS can damage proteins, deoxynucleic acid, and lipid bilayer disturbing cell and integrity, and causing cell death via apoptosis (JACOBSON, 1996). Emerging evidence indicates that ROS inhibition could be of significance in the treatment of PD. Besides the above-mentioned enhancement in apoptotic proteins oxidative stress is proven to be implicated in 6-OHDA (6-hydroxydopamine) induced toxicity. Neurotoxicity induced by 6-OHDA accompanied by inducing lipid peroxidation and decreasing antioxidant capacity (LI et al., 2008; OUYANG; SHEN, 2006). The 
delineation of biochemical pathways involved in neuronal cell death due to 6-OHDA may aid in the development of drugs for the treatment of various neurodegenerative diseases. The neurotoxic effect of 6-OHDA involves the accumulation of toxins in catecholaminergic neurons, alteration in cellular homeostasis, and neuronal damage (SIMOLA; MORELLI; CARTA, 2007). Currently, there is great interest in discovering novel bioactive components from natural resources. Chemical investigations of several plant species have demonstrated the presence of various bioactive compounds such as flavonoids, triterpenes, and tannins that have proven antioxidant activity. Recently, epidemiological findings suggest that the consumption of natural compounds rich in two classes of polyphenols, anthocyanins, and proanthocyanidins, may reduce the risk of PD (GAO et al., 2012). The proanthocyanidins (PAs), are oligomers or polymers of monomeric flavan-3-ols that can be isolated from various types of grapes (Vitis vinifera L). Proanthocyanidin also known as condensed tannins, are the most abundant plantderived polyphenols (BLADÉ et al., 2016) and induce antineoplastic effects through apoptosis induction in human colon carcinoma cells (KAUR et al., 2008). In recent years, considerable attention has been paid to proanthocyanidins and their monomers due to the potential beneficial effects on human health, including immunomodulatory, antiinflammatory, anticancer, antioxidant, cardio-protective, and antithrombotic properties (JEREZ et al., 2007). The grape seed extract is composed mainly of gallic acid, (+)catechin, and (-)-epicatechin (SMERIGLIO et al., 2017). In addition, these grape seed extracts have been found to provide a beneficial effect impact on cytotoxic-induced stress affecting different organs (ABEER E. ABD EL-WAHAB, HALA EL-ADAWI, 2008; SAAD; YOUSSEF; EL-SHENNAWY, 2009; SAFWEN et al., 2015). More specifically, grape seed extract effectively protects the brain against ischemic stroke in rats, and its antioxidant and free radical scavenging properties are related to this effect (SAFWEN et al., 2015). Despite these beneficial consequences, grape seed extract has been granted increased consideration as a natural antioxidant and neuroprotective agent for neurodegenerative disorders. In this context, we investigated the potential protective effects of proanthocyanidins on 6-OHDA-induced cytotoxicity in PC12 cells, a wellcharacterized in vitro PD model, as well as the related underlying mechanisms with focus on oxidative stress and apoptosis.

\section{MATERIALS AND METHODS}


Drugs

All the materials for cell culture were purchased from Gibco® BRL (Carlsbad, CA, USA) and Life Technologies (Grand Island, NY, USA), and PE Annexin V apoptosis detection assay kit I was purchased from BD PharmigenTM. 6-Hydroxydopamine hydrochloride, 3-(4,5-dimethylthiazol-2-yl)-2,5-diphenyltetrazolium bromide (MTT), protease inhibitor cocktail, were purchased from Sigma-Aldrich (Missouri, USA). Antibodies for the detection of cleaved caspase-3 and cleaved caspase-7 were purchased from Cell Signaling Technology (Beverly, MA, USA). All other drugs were of analytical grade.

Phytochemical analysis

Grape seeds (Vitis vinifera L., Vitaceae, vatiety Seibel 2) were obtained from Vitivinícola Santa Maria S.A., Lagoa Grande, Pernambuco, Brazil. The seeds extract's humidity was standardized to $3 \%$ before the beginning of the experiments. The extraction method has been previously described by Frangi et al. (FRANGI, ENRICO, BERTANI; MUSTICH; TUCCINI, 1996) and Liu et al. (LIU et al., 2012). The polyphenols content was analyzed by the vanillin- $\mathrm{HCl}$ assay as described by Nakamura et al. (NAKAMURA; TSUJI; TONOGAI, 2003).

High performance liquid chromatography (HPLC)

Detection and quantification of proanthocyanidins were carried out using Shimadzu SPD-10VP consisted of ultraviolet (UV) detector, a $20 \mu 1$ injection loop, and Hypersil GOLD $\mu \mathrm{cm}$, dimensions of $4.6 \mathrm{~mm} \times 250 \mathrm{~mm}$, running time $25 \mathrm{~min}$, wavelength $280 \mathrm{~nm}$. The mobile phase was used for water/acetonitrile/phosphoric acid (1000:1) with a flow rate of $1.0 \mathrm{ml} . \mathrm{min}-1$. The eluted samples were detected by a UV detector at $210 \mathrm{~nm}$. The peaks obtained in HPLC were identified by photodiode array (PDA) spectra and by comparison with published data.

\section{Cell culture}

Rat pheochromocytoma cells (PC12 cells) were obtained from the Cell Bank of the Rio de Janeiro (APABCAM, RJ, Brazil) and were cultivated in HAM F12 medium, supplemented with $2.5 \%$ heat-inactivated fetal bovine serum, $15 \%$ heat-inactivated horse serum, $50 \mathrm{U} / \mathrm{ml}$ penicillin and $10 \mathrm{mg} / \mathrm{ml}$ streptomycin. Cultures were maintained in a 
humidified atmosphere of $5 \%$ of $\mathrm{CO} 2$ at $37^{\circ} \mathrm{C}$. PC12 cells were seeded in 96-well plates (24 h) and cells were pretreated with proanthocyanidins $(100 \mu \mathrm{g} / \mathrm{ml})$ in $15 \mathrm{~min}$ before incubating with 6-OHDA $(100 \mathrm{mM})$ for an additional $24 \mathrm{~h}$.

\section{Measurement of cell viability}

Cell viability was measured by quantitative colorimetric assay with MTT (3-(4,5dimethylthiazol-2-yl)-2,5-diphenyltetrazolium bromide), assessing the mitochondrial activity. The cells were exposed to $50 \mu \mathrm{g} / \mathrm{mL}$ and $100 \mu \mathrm{g} / \mathrm{ml}$ of proanthocyanidins and 15 min later 6-OHDA $(100 \mu \mathrm{M})$ was added. After $24 \mathrm{~h}$ of incubation, the medium was replaced and MTT was added to the cell culture at a final concentration of $0.5 \mathrm{mg} / \mathrm{ml}$ and incubated again for $3 \mathrm{~h}$. Then, the medium was removed and the purple formazan crystals were dissolved in $150 \mu \mathrm{L}$ DMSO for 30 min under stirring. The absorbance was measured with a microplate reader at $550 \mathrm{~nm}$ (Asys UVM 340 microplate reader). The inhibition of MTT reduction to formazan indicates 6-OHDA-induced toxicity. Experiments were performed in triplicates on three different days. Cell viability was expressed as a percentage of controls (cells not exposed to 6-OHDA no drugs).

\section{Measurement of nitrite production}

The production of nitrite was measured according to Green et al. (GREEN; TANNENBAUM; GOLDMAN, 1981). After cells treatments, $100 \mu 1$ of the cell culture medium was added to $100 \mu \mathrm{l}$ of Griess reagent (1\% sulfanilamide in $1 \% \mathrm{H} 3 \mathrm{PO} 4 / 0.1 \% \mathrm{~N}$ (1-naphthyl)-ethylenediamine dihydrochloride/1\% H3PO4/distilled water, 1:1:1:1), and the mixture was incubated at room temperature for $10 \mathrm{~min}$. The standard curve was prepared with several concentrations of $\mathrm{NaNO} 2$ (ranging from 0.75 to $100 \mu \mathrm{M}$ ) under the same conditions. Blanks were prepared by adding $100 \mu \mathrm{l}$ of the Griess reagent to $100 \mu \mathrm{l}$ of the culture medium. The absorbance was measured with a microplate reader at $560 \mathrm{~nm}$.

\section{Determination of production of thiobarbituric acid-reactive substance (TBARS)}

The antioxidant activity was evaluated by measuring the thiobarbituric acid reactive substances (TBARS), an indicator of lipid peroxidation. After treatments, the supernatant was discarded, and PC12 cells were lysed with $1 \mathrm{ml}$ of Triton X-100 (0.2\%). Then, $250 \mu \mathrm{l}$ of the lysed cells was incubated in a water bath at $37^{\circ} \mathrm{C}$ for $1 \mathrm{~h}$, followed by the addition of $400 \mu \mathrm{l}$ of $35 \%$ perchloric acid to stop lipid peroxidation. The mixture was 
centrifuged at $300 \mathrm{xg}$ for $10 \mathrm{~min}$, and $200 \mu \mathrm{l}$ of $0.8 \%$ sodium 2-thiobarbiturate solution was added to the supernatant $(600 \mu \mathrm{l})$. The mixture was then placed in a water bath and heated again at $95^{\circ} \mathrm{C}$ for $30 \mathrm{~min}$. After cooling, absorbances were measured with a microplate reader at 535nm (MIHARA; UCHIYAMA, 1978). The concentrations of TBARS were calculated using 1,1,3,3-tetramethoxypropane as a reference standard. Data were reported as mean \pm SEM for three independent experiments.

\section{Determination of intracellular glutathione (GSH) content}

Reduced glutathione (GSH) was determined according to the method described by Ellman (ELLMAN, 1959) with some modifications. Cells were washed twice with cold phosphate-buffered saline (PBS). After treatments, the cells were subsequently scraped and collected in $1 \mathrm{~mL}$ of PBS and centrifuged at 400xg for $5 \mathrm{~min}$. After that, the pellet was lysed with $400 \mu \mathrm{l}$ of lysate buffer (Triton $0.2 \%$ ). Aliquots (300 $\mu \mathrm{L}$ ) of supernatant were mixed with $100 \mu$ of trichloroacetic acid (TCA) $50 \%(\mathrm{w} / \mathrm{v})$ in glass tubes and centrifuged at 500xg for $5 \mathrm{~min}$. The amount of proteins in the supernatant was determined by the Lowry method with bovine serum albumin as the standard. DTNB 10 $\mathrm{mM}$ was added to the supernatant and the absorbance was measured at $412 \mathrm{~nm}$ within 5 min. The GSH concentration ( $\mu \mathrm{g} / \mathrm{g}$ of wet tissue) was computed from a standard curve.

\section{Determination of apoptosis by flow cytometry}

The rate of apoptosis was detected using Annexin V-7-AAD Apoptosis Detection Kit (Becton Dickinson) according to the manufacturer's instructions. Briefly, after treatments, the medium was discarded, and cells were trypsinized and washed with PBS three times. The washed cells were re-suspended in binding buffer followed by mixing with $5 \mu \mathrm{L}$ Annexin V-7-AAD. The cells were incubated in the dark for $15 \mathrm{~min}$ at room temperature. Samples were analyzed by flow cytometry (BD Bioscience FACS verse).

\section{Western blot analysis}

The cells were cultured at a density of $5 \times 105$ cells $/ \mathrm{mL}$ in a $60 \mathrm{~mm}$ culture dish at $37^{\circ} \mathrm{C}$ overnight. The cells were pretreated with $100 \mu \mathrm{g} / \mathrm{mL}$ of proanthocyanidins for 15 min, then exposed to 6-OHDA $(25 \mu \mathrm{g} / \mathrm{mL})$ or vehicle for $24 \mathrm{~h}$. After incubations, the medium was collected and cells were washed three times with cold PBS and lysed directly on culture plates with RIPA lysis buffer $(50 \mathrm{mmol} / \mathrm{L}$ Tris- $\mathrm{HCl}, 150 \mathrm{mmol} / \mathrm{L} \mathrm{NaCl}, 1 \%$ 
Nonidet-40, 0.5\% sodium deoxycholate, 1 mmol/L EDTA, 1 mmol/L PMSF). Cell lysates were centrifuged at $14,000 \mathrm{~g}$ for $20 \mathrm{~min}$ at $4{ }^{\circ} \mathrm{C}$, and protein concentrations were determined by Lowry (Bio-Rad, EUA). Equivalent amounts of protein (50 $\mu \mathrm{g}$ ) were loaded and separated by $12 \%$ SDS-PAGE gels and transferred to PVDF membranes. Membranes were blocked with $5 \%$ nonfat milk solution in tris-buffered saline with $0.1 \%$ Tween-20 (TBST) for $1 \mathrm{~h}$, and then incubated overnight at $4^{\circ} \mathrm{C}$ with the primary antibodies: anti-caspase-3 (1:1000), anti-cleaved caspase-3 (1:1000), anti-caspase-7 (1:700), anti-cleaved caspase-7 (1:700), diluted in TBST. After that, the membranes were washed and incubated with secondary antibodies for $1 \mathrm{~h}$ at room temperature. After incubation, they were washed three times for 5 min with TBST and incubated with ECL (Enhanced chemiluminescent substrate, Bio-Rad, USA) for $5 \mathrm{~min}$. The density of chemiluminescence bands was measured using Imager LabTM software (Bio-Rad).

\section{Statistical analysis}

All values are expressed as mean \pm standard error mean (S.E.M.). The differences between groups were analyzed using one-way ANOVA followed by Newman Keul's post-hoc test. Differences were considered significant at $\mathrm{p}<0.05$.

\section{RESULTS}

\section{Proanthocyanidin content}

The proanthocyanidins were obtained through the methanolic extraction from grape seeds, followed by their purification. The extraction process used was described by Frangi et al. (FRANGI, ENRICO, BERTANI; MUSTICH; TUCCINI, 1996) and allows the final product to be obtained in a standardized manner, i.e. after being extracted, it is processed for the selective removal of undesirable impurities such as grape seed oils, monomers, polymers, and resins. After complete extraction of the proanthocyanidins from the grape seed, the crude extract was purified as described by Frangi et al. (FRANGI, ENRICO, BERTANI; MUSTICH; TUCCINI, 1996) and Liu et al. (LIU, 2012) and using liquid-liquid extraction. Once the monomers and polymers were removed, the organic phase was then concentrated and dried to yield the standardized grape (LIU, 2012) seed extract containing the proanthocyanidins. The grape seed extract prepared by this method has a $96.5 \%$ proanthocyanidins content, as determined by the vanillin- $\mathrm{HCl}$ method and measured as total flavan-3-ol (NAKAMURA; TSUJI; TONOGAI, 2003). 
High performance liquid chromatography analysis

The complete separation of all the components of the standard grape seed extract by chromatographic methods (using reverse phase RP-HPLC) is very difficult due to the numerous polyphenolic substances with a large number of hydroxyls and many types of isomers (Figure. 1), which is in agreement with Nakamura et al. (NAKAMURA; TSUJI; TONOGAI, 2003) only low molecular weight phenolic substances can be determined by this method (Figure. 2). Also, all chromatograms of the standardized grape seed extracts show a broad peak after 27 minutes suggesting that this broad peak is a mixture of high molecular weight proanthocyanidins. Using the method described by Nakamura et al. (NAKAMURA; TSUJI; TONOGAI, 2003) the smaller weight polyphenols were quantified and the following results were obtained: gallic acid (Retention time $(\mathrm{Rt})=$ $10.00 \mathrm{~min}, 0.20 \pm 0.02 \%)$, procyanidin $\mathrm{B} 1(\mathrm{Rt}=20.57 \mathrm{~min}, 0.75 \pm 0.02 \%)(+)$-catechin $(\mathrm{Rt}$ $=21.80 \mathrm{~min}, 1.70 \pm 0.08 \%)$, procyanidin $\mathrm{B} 2(\mathrm{Rt}=23.62 \mathrm{~min}, 97.00 \pm 0.01 \%)(-)-$ epicatechin $(\mathrm{Rt}=24.06 \mathrm{~min}, 1.30 \pm 0.12 \%)$, procyanidin $\mathrm{C} 1(\mathrm{Rt}=25.51,2.05 \pm 0.1 \%)$.

Figure 1 - HPLC chromatogram of proanthocyanidins in grape seed extracts.

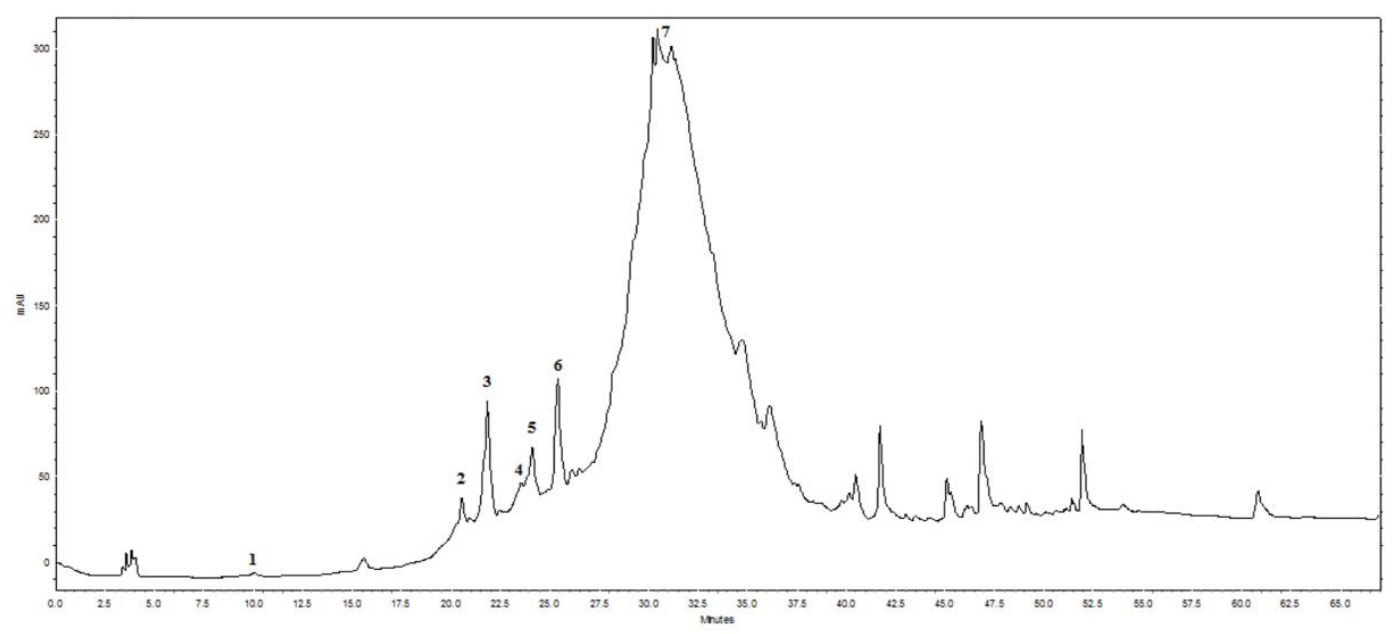


Figure 2 - Chemical structure of proanthocyanidins.<smiles>Cc1cc(O)cc2c1C(c1c(O)ccc3c1O[C@H](c1ccc(O)c(O)c1)[C@H](O)C3c1c(O)ccc(O)c1O[C@H](c1ccc(O)c(O)c1)[C@H](O)c1ccc(O)c(O)c1)[C@H](O)C2</smiles>

Proanthocyanidins protected PC-12 cells against 6-OHDA-induced cytotoxicity

As indicated in Figure.3, proanthocyanidin pretreatment showed a significant increase in the cell survival rate as compared to cells treated with 6-OHDA. The percentage survival rate for cells treated with 6-OHDA alone for $24 \mathrm{~h}$ was $53.4 \%$. Treatment with 50 and $100 \mu \mathrm{g} / \mathrm{ml}$ of proanthocyanidins increased cell viability to $55.22 \%$ and $73.4 \%$ respectively. PC12 cells viability was not affected after $24 \mathrm{~h}$ of proanthocyanidin exposure alone. This suggests that proanthocyanidin could effectively protect PC12 cells from 6-OHDA induced cell death. 
Figure 3 - Effects of proanthocyanidins on 6-OHDA induced cytotoxicity.

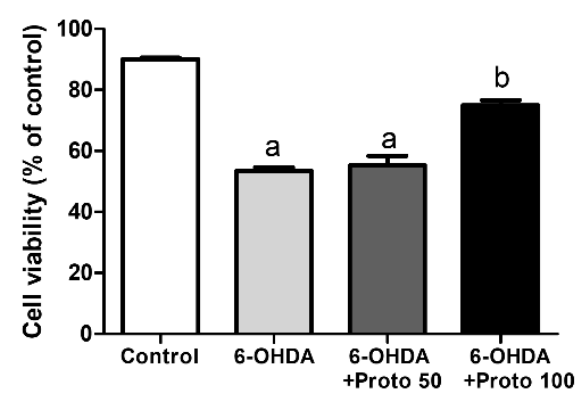

Proanthocyanidins attenuated 6-OHDA-induced oxidative stress

Exposure of PC12 cells to 6-OHDA significantly increased nitrite concentration and this effect was prevented by the pretreatment with proanthocyanidins $100 \mu \mathrm{g} / \mathrm{ml}$ $(\mathrm{p}<0.05$; Figure. 4A). The pretreatment with proanthocyanidins $100 \mu \mathrm{g} / \mathrm{mL}$ also prevented 6-OHDA-induced lipid peroxidation $(\mathrm{p}<0.05$; Figure. $4 \mathrm{~B})$. Another way to determine the antioxidant properties of proanthocyanidins against 6-OHDA toxicity in PC12 cells was to evaluate the GSH levels. 6-OHDA decreased GSH levels, and proanthocyanidins restored GSH to values to close the control group. Content cells exposed to 6-OHDA, the level of activity in the cells treated with proanthocyanidins was significantly increased ( $\mathrm{p}<0.05$; Figure. $4 \mathrm{C})$.

\section{Proanthocyanidins attenuated 6-OHDA-induced apoptotic cell death}

As shown in Figure. 5A, PC12 cells were labeled with both 7-AAD and PE Annexin $\mathrm{V}$ to determine the percentage of apoptotic cells. In the control group, most cells were viable (viable cells: 87.4\%; inviable cells: $12.6 \%$ ). When the PC12 cells were exposed to 6-OHDA, the percentage of early apoptotic (PE Annexin V) and late apoptotic (7-AAD) cells was significantly increased to $37.0 \%$ and $55.3 \%$, respectively (Figure. 5B and 5D). Pretreatment with proanthocyanidins $100 \mu \mathrm{g} / \mathrm{ml}$ resulted in a markedly reduced number of 6-OHDA-induced cells labeled with PE Annexin V (13.8\%) and 7-AAD (37.0\%) (Figure. 5C and 5D), confirming that proanthocyanidins can prevent 6-OHDAinduced apoptosis in PC12 cells ( $\mathrm{p}<0.05)$. 
Figure 4 - Effects of proanthocyanidins on oxidative stress in PC-12 cells exposed to 6-OHDA $(100 \mu \mathrm{M})$.
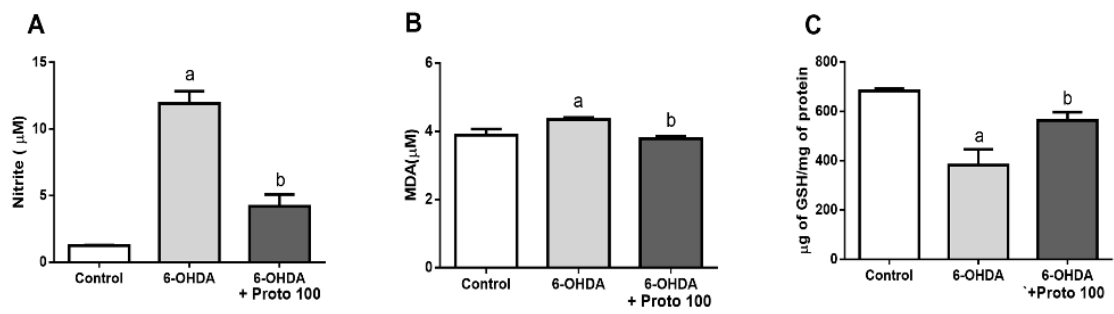

Figure 5 - Effects of proanthocyanidins on the standard apoptosis in cultured PC12 cells
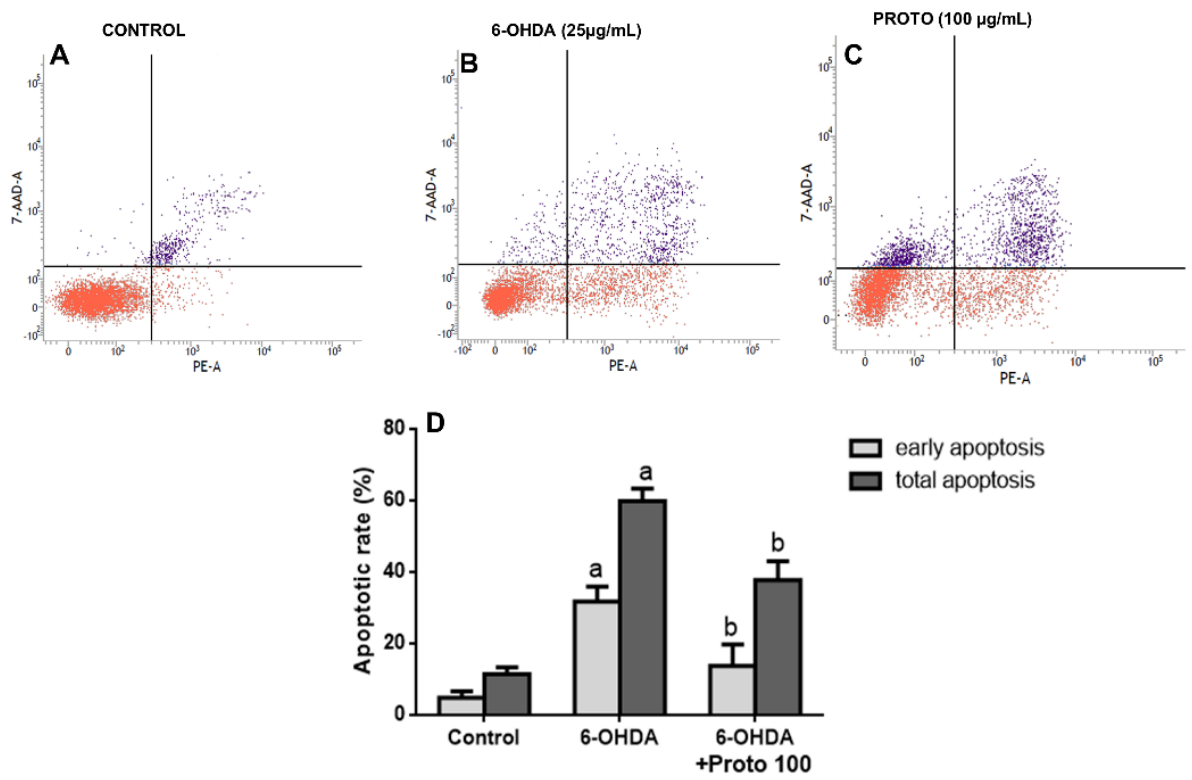

$\square$ early apoptosis

Involvement of cleaved caspase- 3 and -7 in neuroprotection by proanthocyanidins

The results obtained lead to the investigation of the expression of cleaved caspase protein expression after cell exposure to 6-OHDA. The density of cleaved caspase-3 and cleaved caspase-7 were increased in cells exposed to 6-OHDA $(100 \mu \mathrm{M})$ for $24 \mathrm{~h}$. 
However, pretreatment with proanthocyanidins $100 \mu \mathrm{g} / \mathrm{ml}$ downregulated the expression of caspase-3 and caspase-7 when compared to the normal control (Figure. 6).

Figure 6 - Effects of proanthocyanidins on caspase-3 and caspase-7 activation in 6-OHDA treated PC12 cells.
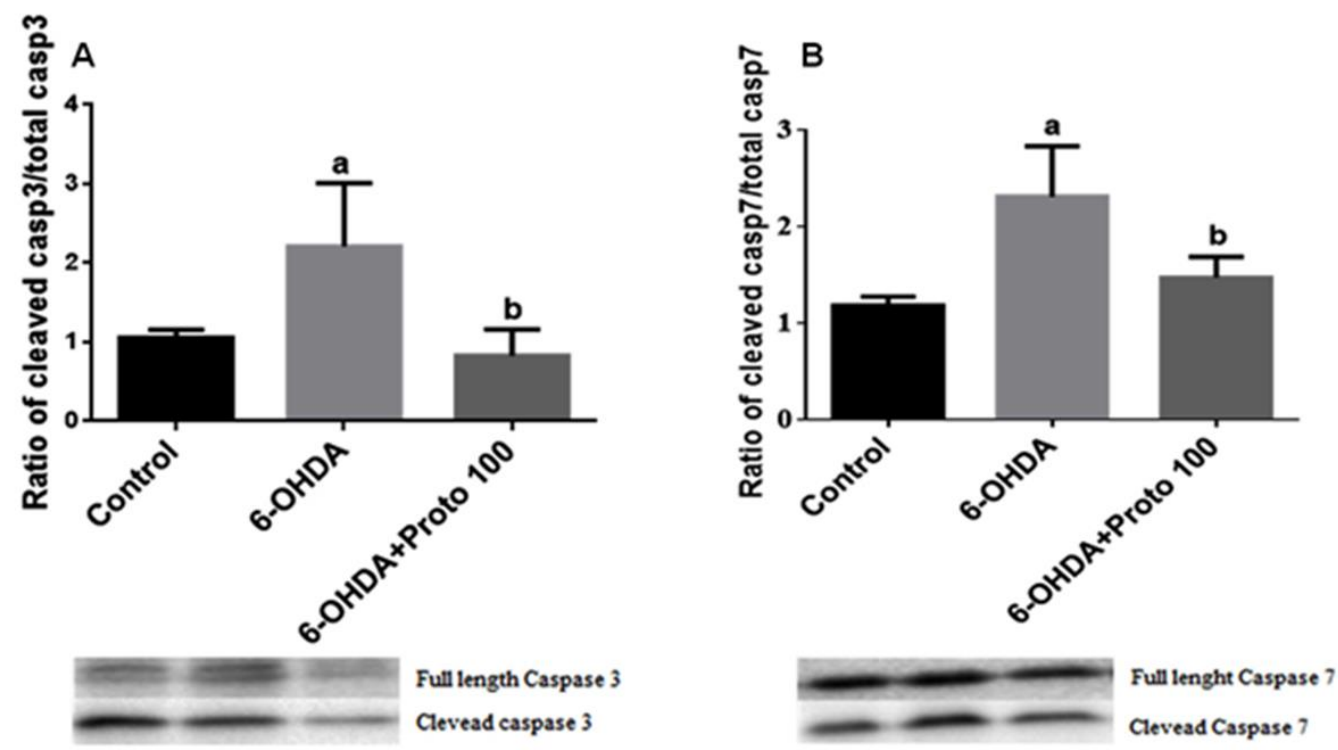

\section{DISCUSSION}

Parkinson's disease is a progressive neurodegenerative disease of the central nervous system which impairs movement and speech. Despite the advances in medical sciences and several studies that have centered on understanding the pathogenesis and mechanism involved in PD, very little progress has been made in understanding the complexity and the intricacy of the pathophysiology of the disease. A great number of studies have shown that antioxidants can protect nervous tissue from 6-OHDA-caused damage. This study was designed to investigate the antioxidant and neuroprotective effects of proanthocyanidins on cytotoxicity induced by 6-OHDA. 6-hydroxydopamine, a neurotoxin, has been widely used in inducing PD-like models, and cause degeneration of dopamine neurons in animal models as well as cause cell apoptosis in PC12 cells (GLINKA; YOUDIM, 1995; XU et al., 2001).

Previous studies have found that the primary cause of 6-OHDA-induced cytotoxicity is ROS or oxidized products produced through 6-OHDA oxidation (SAITO et al., 2007). Our results reveled that, the pretreatment of PC12 cells with $100 \mu \mathrm{g} / \mathrm{ml}$ of 
proanthocyanidins reduced both cell damage and cell dysfunction, preventing cytotoxicity caused by 6-OHDA. According to research evidence, Strathearn and coworkers (STRATHEARN et al., 2014) demonstrated that extracts rich in anthocyanins and proanthocyanidins exhibited greater neuroprotective activity than extracts rich in other polyphenols in a primary midbrain cell culture model exposed to rotenone, a PDinducing chemical. The authors suggested that anthocyanins and proanthocyanidins activate pro-survival pathways involved in mitochondrial function which are essential for the viability of neurons. In addition, consistent with this finding, cocoa extract rich in proanthocyanidins was found to reduce nigral dopaminergic cell death and striatal dopamine depletion in rats exposed to 6-OHDA, whereas catechin-rich extracts from the seeds of red or white grapes showed little evidence of neuroprotective activity in the same model (DATLA et al., 2007). However, other studies have shown that monomeric proanthocyanidins such as catechin and (-)-epigallocatechin-3-gallate and extracts rich in these polyphenols are neuroprotective in cellular and rodent models of PD (GUO et al., 2007; TEIXEIRA et al., 2013). High intracellular ROS levels might seriously compromise the functionality of cellular organelles over time. Lipid peroxidation is the result of interactions between free radicals of diverse origins and unsaturated fatty acids and lipids. These free radicals react instantaneously with membrane lipids and cause lipid peroxidation and cell death (LU et al., 2006). In this study, we observed that 6-OHDA induced lipid peroxidation, as indicated by the increase of malondialdehyde (MDA) levels in PC12 cells, and proanthocyanidins significantly attenuated this effect (PAVLICA; GEBHARDT, 2010). Pretreatment with proanthocyanidins also prevented the increase of NO levels induced by 6-OHDA. In a previous study demonstrated that proanthocyanidins in grape seeds can reduce MDA contents, inhibit NOS activity and lower NO, IL-1 $\beta$, TNF- $\alpha$, and PGE2 in exudate from edema paws of rats induced by carrageenan (LI et al., 2001). A systematic review and meta-analysis study analyzed relevant data regarding the efficacy of proanthocyanidins against oxidative damage. The authors found that proanthocyanidins intervention increases the levels of the antioxidative indicators superoxide dismutase (SOD) and catalase, reduced glutathione (GSH) and glutathione peroxidase (GPx), and decreased the concentration of MDA in mouse models of oxidative, showing a clear antioxidant effect (LI et al., 2015; ZHAO et al., 2014). One of the earliest detectable events during PD is a significant decrease in cellular levels of GSH in the substantia nigra Cells neutralize free radicals by enzymatic and non-enzymatic 
mechanisms. Non-enzyme antioxidants such as reduced glutathione, is key components of the cellular defense (KAUR et al., 2009). In the present study, we observed that the total thiol concentration was found to be significantly decreased in 6-OHDA group as compared to control, but there was a significant increase of these levels in the cells treated with proanthocyanidins. This result is consistent with previous study from Martín et al. (MARTÍN et al., 2013) in which Merlot red wine extract, rich in compounds such as quercetin, catechin, epicatechin, tyrosol, gallic acid, and procyanidins, attenuated ROS production and decreased the redox index of glutathione in PC12 cells. In addition, it has been demonstrated that grape seed proanthocyanidins can reduce the oxidized glutathione accumulation in Zucker rats, thus increasing the total GSH/oxidized glutathione hepatic ratio and consequently elevated the total antioxidant capacity of the cell (FERNÁNDEZIGLESIAS et al., 2014). Oxidative stress, distinguished by an increasing in development of oxidative stress lack of appropriate antioxidant protection, reactive species of oxygen or nitrogen have been stated in clinical and biochemical study results to play a significant role in the diagnosis of several disorders (MITTLER, 2002). Oxidative stress leads to the inflammatory mechanisms of disorders including diabetes mellitus, cancer, rheumatoid arthritis, cardiovascular diseases and neurological conditions such as Parkinson's and Alzheimer's (VALKO et al., 2007). Apart from oxidative stress, apoptosis has also been regarded as a central mechanism for the injury of PD (GREEN, 1998). Excessive production of ROS could trigger the apoptotic process in DA neurons (FISKUM et al., 2003). Proanthocyanidins have numerous biological activities and should not be considered only as free radical scavengers. They decrease tumor cell proliferation by enhancing apoptotic mechanisms, but they can also delay cellular decline and inhibit programmed cell death without compromising the function of normal cells (PUIGGRÒS et al., 2014). In this study, we reported that exposure of cells to $100 \mu \mathrm{M}$ of 6-OHDA induces oxidative stress by initiating a sequence of events that reduce cellular activity and lead to apoptotic cell death. 6-OHDA-induced apoptosis was confirmed by annexin V-PE staining. Proanthocyanidins pretreatment reduced early and late apoptosis and inhibited activation of Caspase-3 and Caspase-7. Although it is not clearly elucidated how proanthocyanidins defend against cytotoxicity in 6-OHDA induced PC12 cells, modulation of activation of Caspase-3 and Caspase-7 could correspond to cell viability, and these compounds have been successful in blocking early and late apoptotic processes, as demonstrated by flowcytometry. Several reports have pointed to the fact that 
antioxidant polyphenolic compounds could protect against 6-OHDA induced mitochondrial damage in PC12 cells (MAGALINGAM et al., 2015). Oxidative stressinduced apoptosis via the intrinsic pathway in neurons has been associated with alterations in the Bcl-2 family and the participation of the MAPK family (ZHU et al., 2002). Caspase- 3 is a protease that is usually activated in response to cell death, and it is responsible for catalyzing the breakdown of several vital cellular proteins. The treatment with proanthocyanidins could attenuate the toxicity of 6-OHDA, suggesting that proanthocyanidins could protect against 6-OHDA induced mitochondrial damage in PC12 cells. A previous study demonstrated that cocoa procyanidin fraction (CPF) attenuated the intracellular ROS accumulation and apoptosis induced by HNE, one of the aldehydic products of membrane lipid peroxidation in PC12 cells. CPF and procyanidin B2 also prevented HNE-induced poly (ADP-ribose) polymerase cleavage, antiapoptotic protein (Bcl-2 and Bcl-XL) down-regulation, and caspase-3 activation (CHO et al., 2009). Despite the accumulating data on proanthocyanidins antioxidative and antiapoptotic effects, the mechanisms related to these effects are still unclear. To improve product development and the utilization of proanthocyanidins, it is necessary to characterize the enzymes, receptor genes, and signaling pathways involved in the antioxidation process (MARTINEZ-MICAELO et al., 2012).

\section{CONCLUSION}

In conclusion, the current study revealed that most abundant plant derived polyphenols-proanthocyanidin, a condensed tannin from the grapes (Vitis vinifera L), exhibited neurocytoprotective effects against 6-OHDA-induced cytotoxicity in PC12 cells. Although, several mechanisms have been proposed to contribute to the loss of neurons in PD with increased oxidative stress being strongly implicated. Therefore, these results have important implications and suggest that proanthocyanidins could provide a defense against apoptosis induced by oxidative stress through directly inhibit apoptosis. Furthermore, the grape seed extract could be potential source of promising treatment for a variety of diseases, including Parkinson's disease. Future studies should also focus on the effects of proanthocyanidins and their mechanisms of action and host response in the metabolic pathway. 


\section{REFERÊNCIAS}

ABEER E. ABD EL-WAHAB, HALA EL-ADAWI, H. S. KASSEM. Towards Understanding The Hepatoprotective effect of Grape Seeds Extract on Cholesterol-Fed Rats. Australian Journal of Basic and Applied Sciences, v. 2, n. 3, p. 412-417, 2008.

BAGLIO, F. et al. Functional brain changes in early Parkinson's disease during motor response and motor inhibition. Neurobiology of Aging, v. 32, n. 1, p. 115-124, 2011.

BLADÉ, C. et al. Proanthocyanidins in health and disease. BioFactors, v. 42, n. 1, p. 5$12,2016$.

CHO, E. S. et al. Cocoa procyanidins attenuate 4-hydroxynonenal-induced apoptosis of PC12 cells by directly inhibiting mitogen-activated protein kinase kinase 4 activity. Free Radical Biology and Medicine, v. 46, n. 10, p. 1319-1327, 2009.

DATLA, K. P. et al. Short-term supplementation with plant extracts rich in flavonoids protect nigrostriatal dopaminergic neurons in a rat model of parkinson's disease. Journal of the American College of Nutrition, v. 26, n. 4, p. 341-349, 2007.

DAUER, W.; PRZEDBORSKI, S. Parkinson's disease: mechanisms and models. Neuron, v. 39, n. 6, p. 889-909, 2003.

ELLMAN, G. L. Tissue sulfhydryl groups. Archives of Biochemistry and Biophysics, v. 82, n. 1, p. 70-77, 1959.

FEARNLEY, J. M.; LEES, A. J. Ageing and parkinson's disease: Substantia nigra regional selectivity. Brain, v. 114, n. 5, p. 2283-2301, 1991.

FERNÁNDEZ-IGLESIAS, A. et al. Grape seed proanthocyanidin extract improves the hepatic glutathione metabolism in obese Zucker rats. Molecular nutrition \& food research, v. 58, n. 4, p. 727-37, 2014.

FISKUM, G. et al. Mitochondrial mechanisms of neural cell death and neuroprotective interventions in Parkinson's disease. Annals of the New York Academy of Sciences, v. 991, p. 111-9, 2003.

FRANGI, ENRICO, BERTANI, M.; MUSTICH, G.; TUCCINI, G. Process for preparing grapeseed extracts enriched in procyanidol oligomers. Italy, 1996.

GAO, X. et al. Habitual intake of dietary flavonoids and risk of Parkinson disease. Neurology, v. 78, n. 15, p. 1138-1145, 2012.

GLINKA, Y. Y.; YOUDIM, M. B. H. Inhibition of mitochondrial complexes I and IV by 6-hydroxydopamine. European Journal of Pharmacology: Environmental Toxicology and Pharmacology, v. 292, n. 3-4, p. 329-332, 1995.

GREEN, D. R. Apoptotic pathways: the roads to ruin. Cell, v. 94, n. 6, p. 695-8, 18 set. 1998. 
GREEN, L. C.; TANNENBAUM, S. R.; GOLDMAN, P. Nitrate synthesis in the germfree and conventional rat. Science (New York, N.Y.), v. 212, n. 4490, p. 56-8, 1981.

GUO, S. et al. Protective effects of green tea polyphenols in the 6-OHDA rat model of Parkinson's disease through inhibition of ROS-NO pathway. Biological Psychiatry, v. 62, n. 12, p. 1353-1362, 2007.

JACOBSON, M. D. Reactive oxygen species and programmed cell death. Trends in biochemical sciences, v. 21, n. 3, p. 83-86, 1996.

JEREZ, M. et al. A comparison between bark extracts from Pinus pinaster and Pinus radiata: Antioxidant activity and procyanidin composition. Food Chemistry, v. 100, n. 2 , p. 439-444, 2007.

KAUR, D. et al. Glutathione depletion in immortalized midbrain-derived dopaminergic neurons results in increases in the labile iron pool: Implications for Parkinson's disease. Free Radical Biology and Medicine, v. 46, n. 5, p. 593-598, 2009.

KAUR, M. et al. Grape Seed Extract Induces Cell Cycle Arrest and Apoptosis in Human Colon Carcinoma Cells. Nutrition and Cancer, v. 60, n. sup1, p. 2-11, 2008.

LI, S. et al. Efficacy of Procyanidins against In Vivo Cellular Oxidative Damage: A Systematic Review and Meta-Analysis. PLOS ONE, v. 10, n. 10, p. e0139455, 2015.

LI, W. G. et al. Anti-inflammatory effect and mechanism of proanthocyanidins from grape seeds. Acta pharmacologica Sinica, v. 22, n. 12, p. 1117-20, 2001.

LI, Z. et al. Neurotrophin-3 reduces apoptosis induced by 6-OHDA in PC12 cells through Akt signaling pathway. International Journal of Developmental Neuroscience, v. 26, n. 6, p. 635-640, 2008 .

LIU, S. Extraction and Characterization of Proanthocyanidins from Grape Seeds. The Open Food Science Journal, v. 6, n. 1, p. 5-11, 2012.

LU, Z. et al. Structure-activity relationship analysis of antioxidant ability and neuroprotective effect of gallic acid derivatives. Neurochemistry International, v. 48, n. 4, p. 263-274, 2006.

MAGALINGAM, K. B. et al. Quercetin Glycosides Induced Neuroprotection by Changes in the Gene Expression in a Cellular Model of Parkinson's Disease. Journal of Molecular Neuroscience, v. 55, n. 3, p. 609-617, 2015.

MARTÍN, S. et al. Protective Effects of Merlot Red Wine Extract and its Major Polyphenols in Pc12 Cells under Oxidative Stress Conditions. Journal of Food Science, v. 78, n. 1, 2013.

MARTINEZ-MICAELO, N. et al. Procyanidins and inflammation: Molecular targets and health implications. BioFactors, v. 38, n. 4, p. 257-265, 2012. 
MIHARA, M.; UCHIYAMA, M. Determination of malonaldehyde precursor in tissues by thiobarbituric acid test. Analytical biochemistry, v. 86, n. 1, p. 271-8, 1978.

MITTLER, R. Oxidative stress, antioxidants and stress tolerance. Trends in Plant Science, v. 7, n. 9, p. 405-410, 2002.

MORIGUCHI, S.; YABUKI, Y.; FUKUNAGA, K. Reduced calcium/calmodulindependent protein kinase II activity in the hippocampus is associated with impaired cognitive function in MPTP-treated mice. Journal of Neurochemistry, v. 120, n. 4, p. 541-551, 2012.

NAKAMURA, Y.; TSUJI, S.; TONOGAI, Y. Analysis of Proanthocyanidins in Grape Seed Extracts, Health Foods and Grape Seed Oils. JOURNAL OF HEALTH SCIENCE, v. 49, n. 1, p. 45-54, 2003.

OUYANG, M.; SHEN, X. Critical role of ASK1 in the 6-hydroxydopamine-induced apoptosis in human neuroblastoma SH-SY5Y cells. Journal of Neurochemistry, v. 97, n. 1, p. 234-244, 2006.

PAVLICA, S.; GEBHARDT, R. Protective effects of flavonoids and two metabolites against oxidative stress in neuronal PC12 cells. Life Sciences, v. 86, n. 3-4, p. 79-86, 2010 .

PUIGGRÒS, F. et al. Differential Modulation of Apoptotic Processes by Proanthocyanidins as a Dietary Strategy for Delaying Chronic Pathologies. Critical Reviews in Food Science and Nutrition, v. 54, n. 3, p. 277-291, 2014.

SAAD, A. A.; YOUSSEF, M. I.; EL-SHENNAWY, L. K. Cisplatin induced damage in kidney genomic DNA and nephrotoxicity in male rats: The protective effect of grape seed proanthocyanidin extract. Food and Chemical Toxicology, v. 47, n. 7, p. 14991506, 2009.

SAFWEN, K. et al. Protective Effect of Grape Seed and Skin Extract on Cerebral Ischemia in Rat: Implication of Transition Metals. International Journal of Stroke, v. 10, n. 3, p. 415-424, 2015.

SAITO, Y. et al. Molecular mechanisms of 6-hydroxydopamine-induced cytotoxicity in PC12 cells: Involvement of hydrogen peroxide-dependent and -independent action. Free Radical Biology and Medicine, v. 42, n. 5, p. 675-685, 2007.

SHUI GUAN. et al. Protective effect of protocatechuic acid from Alpinia oxyphylla on hydrogen peroxide-induced oxidative PC12 cell death. European Journal of Pharmacology, v. 538, n. 1-3, p. 73-79, 2006.

SIMOLA, N.; MORELLI, M.; CARTA, A. R. The 6-hydroxydopamine model of Parkinson's disease. Neurotoxicity research, v. 11, n. 3-4, p. 151-67, 2007.

SMERIGLIO, A. et al. Proanthocyanidins and hydrolysable tannins: occurrence, dietary intake and pharmacological effects. British Journal of Pharmacology, v. 174, p.12441262, 2017. 
STRATHEARN, K. E. et al. Neuroprotective effects of anthocyanin- and proanthocyanidin-rich extracts in cellular models of Parkinson's disease. Brain Research, v. 1555, p. 60-77, 2014.

TEIXEIRA, M. D. A. et al. Catechin attenuates behavioral neurotoxicity induced by 6OHDA in rats. Pharmacology Biochemistry and Behavior, v. 110, p. 1-7, 2013.

VALKO, M. et al. Free radicals and antioxidants in normal physiological functions and human disease. The International Journal of Biochemistry \& Cell Biology, v. 39, n. 1, p. 44-84, 2007.

XU, R. et al. Ribozyme-mediated inhibition of caspase-3 activity reduces apoptosis induced by 6-hydroxydopamine in PC12 cells. Brain research, v. 899, n. 1-2, p. 10-9, 2001.

ZHAO, Y.N. et al. The neuroprotective effects of grape seed proanthocyanidin on rat brain injury caused by chronic intermittent hypoxia. NEUROLOGY ASIA, v. 19, n. 4, p. 399-403, 2014.

ZHU, X. et al. The Role of Mitogen-Activated Protein Kinase Pathways in Alzheimer's Disease. Neurosignals, v. 11, n. 5, p. 270-281, 2002. 